\title{
INNOVATING AND GROWING SERVICE-BASED ENTREPRENEURIAL BUSINESS - DEVELOPMENT MODEL BASED ON EUROPEAN AND ASIAN CASE STUDIES
}

\author{
KATARZYNA ŁOBACZ \\ University of Szczecin, Faculty of Management and Economics of Services, POLAND \\ e-mail: katarzyna.lobacz@wzieu.pl
}

RECEIVED

ACCEPTED

JEL

CLASSIFICATION

KEYWORDS

ABSTRACT
10 December 2018

28 December 2018

$\mathrm{L} 80, \mathrm{M} 13,031$

service-based business, entrepreneurship, business development, innovation, business growth, qualitative research, case studies

The main purpose of this paper is analysis of development patterns of service-based entrepreneurial businesses in line with their ability to innovate and grow. The qualitative analysis using process perspective is based on cased studies of the early stage companies from Poland, UK, Vietnam and Indonesia. The study, using systematic grounded theory approach was conducted in the years 2010-2018. The analysis reveals similar development patterns of service-based entrepreneurial businesses in all countries, thus enabling a formulation of 5-stages development model, which is highly knowledge intensive and allows service-based companies to propose radical innovations at the later stages. By providing insights into innovation generation and implementation by service-based entrepreneurial businesses, results of the study enrich the idea of how innovativeness of small service companies can be measured and supported.

\section{Introduction}

Service sector is usually regarded as less innovative then manufacturing industries. Data from different sources (e.g. OECD, Eurostat, GUS) collected systematically at local and international levels, provide an evidence that product innovations, and most of all disruptive innovations, are results of actions performed by manufacturing companies, which are actively involved in $R \& D$ processes and have capacity to implement new solutions to 
the market. Service sectors in contrast deliver improvement innovations, usually marketing and organisational innovations, with no impact on markets or industry disruption (Łobacz, Niedzielski, 2012, pp. 41-52).

The rise of knowledge economy, however, changes this rule, by providing opportunities to design and implement radical innovations based on knowledge, which is independent on production capacities, and thus growth of knowledge-intensive entrepreneurial ventures (Sallos, Yoruk, Garcia-Perez, 2017), which are different from entrepreneurial ventures known before (Caloghirou, Protogerou, Tsakanikas, 2016). Vital part of knowledge intensive entrepreneurship is formed by knowledge intensive services, which are more and more present in economic systems, in both developed and developing countries (Miles, 2008; Malerba, McKelvey 2018). Since knowledge intensive entrepreneurship is regarded to be under the constant impact of knowledge, including the scientific knowledge sourced from academia (Bonaccorsi, Colombo, Guerini, Rossi-Lamastra, 2013; Łobacz, 2015), it holds the ability to generate more radical innovations. This is however not well documented in research results in the field.

The problem of documentation and evidence may be a result of poor understanding of dynamics of service business. It is pointed explicitly that the research on entrepreneurship has been recognized as static, with tendencies to label entrepreneurial ventures, entrepreneurial activities. As F. Welter, T. Baker, D.B. Aundretsch, W.B. Gartner $(2016$, p. 5) argue "We also typically fail to understand pathways through which ventures started from necessity might sometimes even innovate and grow."

Therefore the main purpose of this paper is analysis of development patterns of service-based entrepreneurial businesses in line with their ability to innovate and grow. The qualitative analysis using process perspective is based on case studies of the early stage companies from Poland, UK, Vietnam and Indonesia. The study, using systematic grounded theory approach was conducted in the years 2010-2018.

\section{Innovation in the entreppreneurial venturing process - theoretical background}

Entrepreneurial venture is regarded as a subject which is taking entrepreneurial actions, in particular actions directed towards discovering and/ or creating economic opportunities, implementing ideas into the market, being constantly involved in making decisions, under uncertainty, regarding product design, use of resources and reward system, with the objective to create value (Wennekers, Thurik,1999; Mazzarol, 2011, pp. 69-109; Henrekson, Stenkula, 2016).

The entrepreneurial spirit, as a feature of the entrepreneur, is reflected in the active undertaking of business ventures. From this perspective, entrepreneurial actions combine two fundamental elements: (1) searching for market opportunities and (2) configuration of resources which enables taking advantage of these market opportunities, which are basic sub-process, whenever entrepreneurial process is regarded (Łobacz, 2012).

But, to innovate and grow, entrepreneurs have to address additionally sub-process related to innovation development. In the process perspective innovation can be defined as a result of transformation of expertise and/ or technological knowledge into its economically useful forms (Arrow, 1962) being a response to perceived market opportunity and taking place in line with market requirements, what is coherent with approach applied in innovation process models (Mitchell, Singh, 1996; Jolly, 1997, pp. 1-30; Vohora, Wright, Lockett, 2004).

Since entrepreneurial activities are considered in relation to innovativeness, activities related exclusively to transformation of knowledge into its economically useful form can be defined and related to the entrepreneurial processes scheme. As the process should have an outcome defined at the end, the effects of actions related 
to creating a product concept are to be also included in the model. Based on those assumptions the process of development of the entrepreneurial market offer has been described as consisting of three separate but strictly interconnected layers (1) activities aimed at creating a product concept associated with transformation of technological knowledge which result in innovation; (2) activities aimed at building a venture concept related to transformation of a market opportunity based on market knowledge which result in a market offer; (3) activities aimed at building organizational competencies related to transformation of resources by using business expertise which result in organizational competencies - as presented at Figure 1.

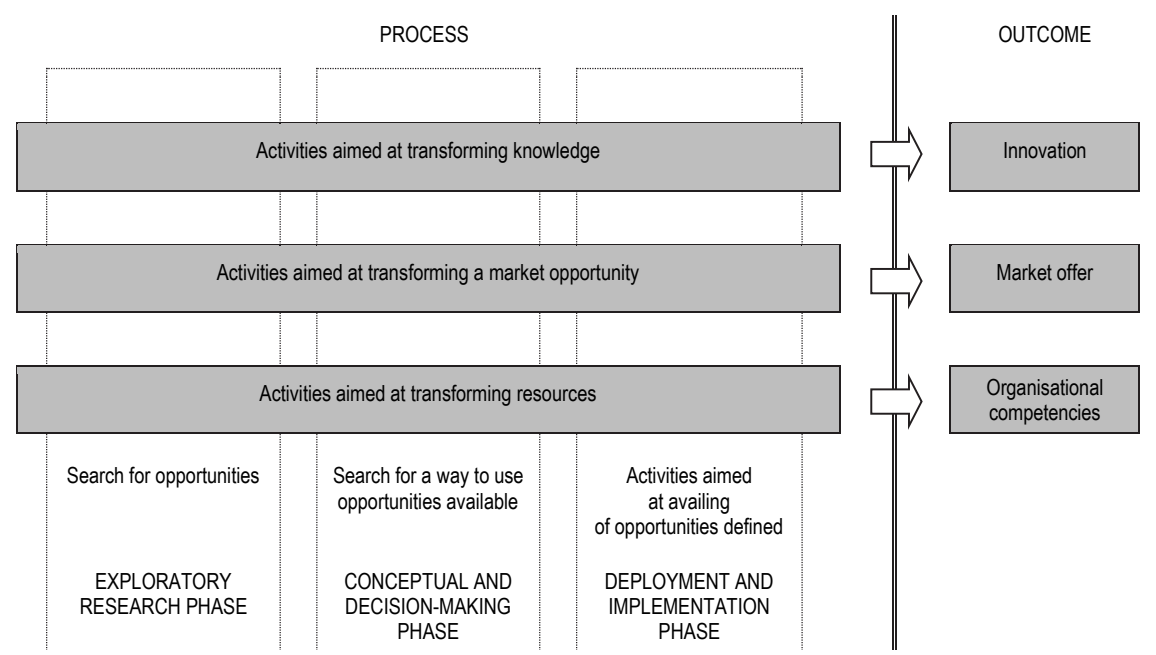

Figure 1. Layers of the process of innovation based entrepreneurial venturing

Source: based on Łobacz (2012).

Based on the presented model, an innovation based entrepreneurial venturing process has been described on the basis of three distinctive but strictly interconnected process layers, as presented on Figure 2.

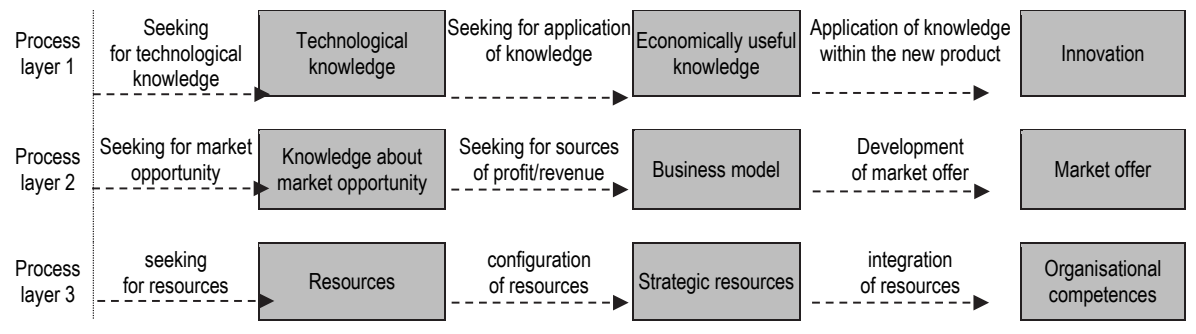

Figure 2. Three layers of an entrepreneurial innovation process model

Source: based on Łobacz (2012). 
Process layer 1 assumes development of the product concept, including especially transformation of technological knowledge from basic knowledge to knowledge used within innovative product, employing capabilities related to seeking for technological knowledge, seeking for application of knowledge and application of knowledge within new products. Process layer 2 relates directly to the main entrepreneurial process element - development of the business concept. It assumes transformation of knowledge about market opportunity into the market offer based on competitive business model, employing capabilities related to seeking for market opportunity, seeking for sources of profit and development of market offer. Process layer 3 encompasses development of the organisational competencies, to include transformation of resources into organisational competences used to propose market offer, employing capabilities related to seeking for resources, configuration of resources and development of market offer.

The model has been designed in order to capture innovation as a growth facilitator of early stage business venture. It's feasibility has been proved in previous studies, to include studies on development of academic entrepreneurship (Łobacz, 2012) and studies of business advise support for small innovative firms (Łobacz, Głodek, 2015).

\section{Method}

The model of innovation based entrepreneurial venturing has been used to analyse development scheme of service-based business ventures. As the analysis is explorative in nature, the multiple case study methodology was used (Yin, 1989, pp. 20-42). This method has been recognised as a valuable approach to the study of small businesses (Chetty, 1996), since it offers a useful framework for analysing the real context, in particular, when the phenomenon is influenced by a number of factors determining each activity (Yin, 1989, pp. 20-42) and its nature is not very clear.

The process of empirical data collection took place using the individual in-depth interview technique. The formula of narrative interview was adopted, hence communication techniques were used in order to focus the discussions on the issues related to the subject of the research, at the same time assuming the greatest possible freedom of expression of the interlocutor.

The in-depth interviews were conducted directly with the owners of small firms. The entrepreneurs were asked about the development context of the company from the beginning of its foundation, milestones of company development and innovations commercialised on the market. The interviews were recorded on digital media, which enabled their repeat use at the stage of data analysis. The study, using systematic grounded theory approach, was conducted in the years 2010-2018 on a group of 104 firms located in Poland, UK, Vietnam and Indonesia.

Within the sampling process a purposeful approach was used, focused on possibly highest diversification of case studies but at the same time fulfilment of predefined features of firms. The following selection criteria were controlled: size of the firm, innovativeness, firms age, sector, gender of the entrepreneur, education of the entrepreneur, impact of external stakeholders on strategic decisions, location.

\section{Development model of service-hased entreppreneurial business}

Determining characteristics of individual layers of innovation focused entrepreneurial process and its analysis over time allowed the identification of five stages in the development of service-based businesses from the time 
of foundation the idea about the venture (not necessarily foundation of a company). Each stage was identified as related to launching successive products onto the market, products characterised by certain level of innovativeness.

The basis for stages recognition was the observation that the nature of the subsequent deployments, and thus the proposed market offer and knowledge used in their implementation, changes along with the development of capabilities and competencies of the company. This means that - in time - the approach to obtaining resources (including knowledge) and the method for their configuration also change within the venture. Thus, subsequent stages are related to higher RENTS, i.e. profit margins from selling particular offering. Taking this fact into consideration, the following stages of business development were distinguished:

Stage 1: launching of a basic offer - which is related to hatching and initiating implementation of one's own vision of the venture; knowledge acquired through education and/or research and teaching work is commercialised; its transformation into a market product is a response to a market opportunity perceived through pursued interests and hobbies as well as being in the environment in which unmet needs are revealed, the business approach is usually typical, without any special features.

Stage 2: improvement of the offer - occurs when entrepreneurs improve their offer, expand it, creating a portfolio of products (mainly service ones); these products are modified on the basis of improved knowledge and it is a customer-driven process as customers require solutions that meet their expectations; market opportunities are perceived through frequent contacts with customers and their communicated needs, on this basis a catalogue of products offered is created; the business approach remains typical, it is, however, more suited to customers' needs.

Stage 3: building partnerships - occurs as a result of changes in philosophy of thinking about business; the offer takes the form of increasingly complex approach to issues related to needs that the company meets; it results from exploration of new possibilities (e.g.: the search for new technological knowledge) as well as increasingly better understanding of market needs which can be met better than they currently are; limited resources make partnership crucial; it enables easy and flexible access to resources, especially ensuring provision of competencies which the company lacks.

Stage 4: standardisation - is based on an expanded partnership; internal knowledge and partners' knowledge is used to create unique products; out of the catalogue of offers those that are rated as the most effective are implemented; there is a tendency for their standardisation.

Stage 5: intense development of innovation - the transition to this phase requires the involvement of the company in their own targeted $R \& D$ activities; the offer is prepared for the needs of broad markets, at least on a national scale, but mostly on an international one (sometimes over a slightly longer time horizon; a gradual entry to new markets); the key to success is access to substantial financial resources (the company's own or external ones) needed for marketing and sales, sometimes also $R \& D$ activities.

As it can be noted, each stage is associated with implementation of a new market offer, however, it is possible to implement several offers at the same stage. This also means that each stage can last for an unlimited amount of time, going through many iterations. The subsequent stages are associated with increasingly higher innovativeness (see Figure 3), along with the development of companies. It is therefore possible to commercialise increasingly advanced expertise/technological knowledge. The further the stage of development, the more the scale of innovativeness of products offered shifts from incremental towards radical one. Not only the idea but also 
knowledge on which it is based is subject to evolution. This, among other things, allows the company to create more advanced products.

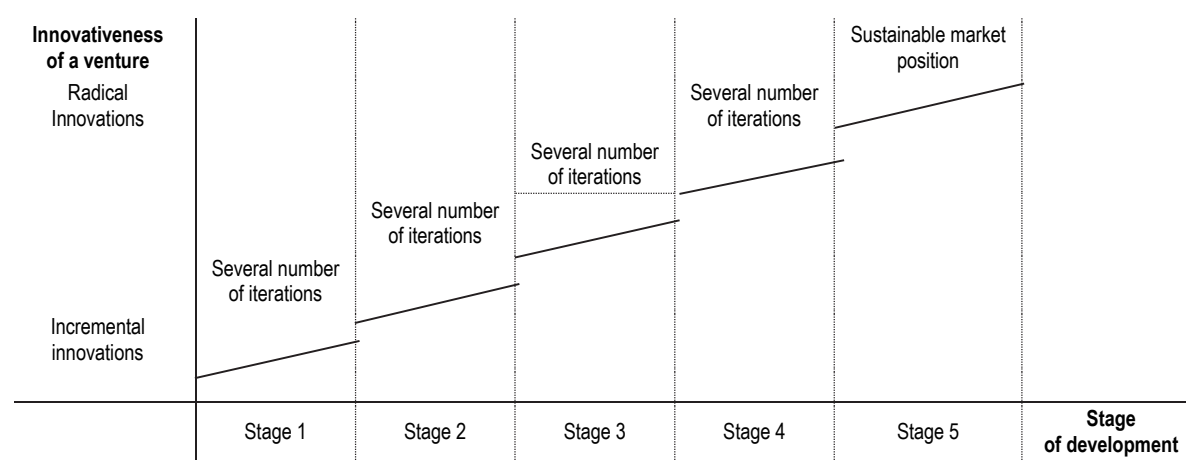

Figure 3. Iterations of the process in relation to innovativeness of a venture

Source: based on Łobacz (2012).

\section{Conclusions}

The model of development has been identified as describing service development in all economic systems, including especially economics poor in scientific knowledge. However new advanced expertise and scientific knowledge related to both product and business issues is crucial for the ability to develop new market offers, and thus innovate and grow. Furthermore the companies are able to grow even if the knowledge is not available in their direct environment. Likewise it was not relevant, whether the entrepreneurs had the expertise or technological knowledge within their internal resources. But it is important whether they can identify the possibility of applying this knowledge to take advantage of a market opportunity. The study confirmed thus results from S.A. Alvarez and L.W. Buzenitz (2011) that one of the essential skills of the entrepreneur is the ability to acquire specialised knowledge and skills of others, as well as to configure resources in such a manner as to be able to reap commercial benefits.

It was observed that, although possible stages of development are similar for all service companies, not all firms go through all the defined development process, and also the speed of development vary significantly. Generally three groups of service-based entrepreneurial ventures were defined: constant developers, moderate developers, and reluctant developers. These were distinguished based on four criterion defined. Constant developers are actively oriented towards improvement in an on-going manner and skip very fast from one stage to another. This is the case of entrepreneurs who (1) are willing to achieve higher rents in their business; (2) are actively and successfully looking for knowledge which will enable them to achieve those rents; (3) are mentally ready for development and (4) are willing to take risk permanently related to any process of development. Reluctant developers, in contrast, are happy with achieved development level (whatever development stage is that) and prefer implementing new offers replicating similar business models and strategies. This is the case of entrepreneurs who (1) are happy with rents achieved; (2) are not very open for new knowledge, don't know where to find it, or don't 
know how to use this knowledge in business practice; (3) are not mentally ready for development and (4) are not willing to take risk permanently related to any process of development. Other firms have moderate development speed - therefore here they are called moderate developers. They usually need time for gaining appropriate in their context knowledge (different kinds) and change mindset in relation to potential rents, readiness for changes and taking risk. For both they need time to be allocated for development issues, as opposed to operational ones (i.e. related to current operations).

The most important finding from this study is identification of the model through which service-based ventures improve their innovativeness, so that they are able to propose to the market disruptive innovations and develop into dynamic big scale businesses. Therefore it is very relevant for knowledge intensive entrepreneurial ventures, but can be used as a roadmap also for less knowledge intensive services. The indicated stages determine the path which the company follows from the moment of defining a business idea to the creation of a mature business. The transition through the subsequent stages means the development of human capital involved in the creation of the venture, in particular in the area of use of specialized (expertise and/or technological) and business knowledge. It is thus noticeable that development of the company requires constant learning process.

Successive iterations within the process, whatever innovativeness is regarded, result in accumulation of resources (i.e. organizational competences) and capabilities (i.e. dynamic capabilities), which are needed to prosper effectively as the firm develops (Łobacz, 2012). When so defined, the presented model in relations to small innovative firm may be regarded as an entrepreneurial innovation cycle model, capturing the competences accumulation process in relation to firm's innovativeness as a stage-based process sensitive to market dynamics.

\section{References}

Alvarez, S.A., Buzenitz, L.W. (2001). The entrepreneurship of resource-based theory. Journal of Management, 27 (12), 755-775.

Arrow, K. (1962). The economic implications of learning by doing. The Review of Economic Studies, 29 (3), 155-173.

Bonaccorsi, A., Colombo, M.G., Guerini, M., Rossi-Lamastra, C. (2014). The impact of local and external university knowledge on the creation of knowledge-intensive firms: evidence from the Italian case. Small Business Economy, 43, 261-287.

Caloghirou, Y., Protogerou, A., Tsakanikas, A. (2016). Knowledge-intensive entrepreneurship: Exploring a taxonomy based on the AEGIS survey. In: F. Malerba, Y. Caloghirou, M. McKelvey, S. Radosevic (eds.), Dynamics of knowledge-intensive entrepreneurship. Business strategy and public policy (pp. 95-120). Routledge.

Chetty, S. (1996). The case study method for research in small and medium-sized firms. International Small Business Journal, 15 (1), 73-85.

Henrekson, M., Stenkula, M. (2016). The Entrepreneurial Rent: The Value of and Compensation for Entrepreneurship. IFN Working Paper No. 1128.

Jolly, V.K. (1997). Commercialising new technologies. USA: Harvard College.

Łobacz, K. (2012). Koncepcja oceny procesu komercjalizacji przedsięwzięć gospodarczych w akademickich inkubatorach przedsiębiorczości w Polsce. PhD dissertation.

Łobacz, K. (2015). Źródła wiedzy warunkującej innowacyjne działania przedsiębiorcze : konserwacje dla sterowania kierunkami rozwoju systemów gospodarczych. Nierówności Społeczne a Wzrost Gospodarczy, 1 (41), 412-431.

Łobacz, K., Głodek, P. (2015). Development of competitive advantage of small innovative firm: how to model business advice influence within the process? Procedia Economics and Finance, 23, 487-494.

Łobacz, K., Niedzielski, P. (2012). Innowacje w sektorze usług - czy różnią się od innowacji w sektorze przemysłowym? In: M. Olszański, K. Piech (eds.), E-biznes - innowacje w Internecie. Jakniektórzy szybko zarobili duże pieniądze? (pp. 41-52). Warszawa: PARP.

Malerba, F., McKelvey, M. (2018). Knowledge-intensive innovative entrepreneurship integrating Schumpeter, evolutionary economics, and innovation systems. Small Business Economy, 1-20. Retrieved from: https://doi.org/10.1007/s11187-018-0060-2.

Mazzarol, T. (2011). Entrepreneurship and innovation. Readings and cases. Australia: Tilde University Press. 
Miles, I. (2008). Knowledge-intensive services. Working paper. Manchester: Manchester Institute for Innovation Research.

Mitchell, W., Singh, K. (1996). Survival of businesses using collaborative relationships to commercialize complex goods. Strategic Management Journal, 17, 169-195.

Sallos, M.P., Yoruk, E., Garcia-Perez, A. (2017). A business process improvement framework for knowledge-intensive entrepreneurial ventures. Journal of Technology Transfer, 42, 354-373.

Vohora, A., Wright, M., Lockett, A. (2004). Critical junctures in the development of university high-tech spinout companies. Research Policy, 33 (1), 147-176.

Welter, F., Baker, T., Aundretsch, D.B., Gartner, W.B. (2017). Everyday Entrepreneurship - A Call for Entrepreneurship Research to Embrace Entrepreneurial Diversity. Entrepreneurship Theory and Practice, 41 (3), 311-321.

Wennekers, S., Thurik, A.R. (1999). Linking Entrepreneurship and Economic Growth. Small Business Economics, 13 (1), $27-55$.

Yin, R.K. (1989). Case study research: design and methods. London: Sage Publications.

Cite this article aS: Łobacz, K. (2018). Innovating and growing service-based entrepreneurial business - development model based on European and Asian case studies. European Journal of Service Management, 4 (28/2), 231-238. DOI: 10.18276/ejsm.2018.28/2-29. 